\author{
I.Ye. Stas \\ Altay State University, Barnaul, Russia \\ (E-mail: irinastas@gmail.com)
}

\title{
The effect of electromagnetic field on silver iodide sols stability
}

\begin{abstract}
It is shown that the influence of the ultrahigh-frequency electromagnetic field on purified water leads to a significant increase in its electrical conductivity and $\mathrm{pH}$. The effect can be interpreted as a change in the supramolecular organization of water. The kinetics of the formation of nuclei of the crystalline phase in irradiated water by the example of silver iodide sols was studied by turbidimetry. It is shown that in the irradiated water the growth of AgI crystals slows down, which is noticed as a slower decrease in the light transmission of the sol in time. The effectiveness of electromagnetic influence depends on the frequency and time of irradiation so that the maximum effect is achieved at the field frequency of $170 \mathrm{MHz}$ and at the irradiation time of 3 hours. Destruction of the sols prepared with irradiated water takes place on the 4th day, while in the control samples it begins after 24 hours. It is assumed that in the irradiated water the growth of crystalline nuclei slows down due to a change in the surface tension and a decrease in AgI solubility.
\end{abstract}

Keywords: water, silver iodide, sol, light transmission, stability, electromagnetic field, frequency, irradiation time.

\section{Introduction}

The problem of the disperse systems stability is one of the most important in colloid chemistry. It is of great importance in many processes occurring in nature and used in the national economy. Ensuring the freedisperse systems stability is necessary in the production of various products, coatings, binders, medicines, aerosols, etc. Destruction of stability is required to cause structure formation in materials, to obtain precipitation during phase separation, to purify industrial emissions. The stability of hydrosols is affected by various factors, namely, heating and cooling, mechanical stirring, the introduction of electrolytes into the system [1]. Another possibility to control the disperse systems stability is the effect of physical fields of various nature as ultrasonic, permanent magnetic and electric, electromagnetic field, as evidenced by numerous publications [2-8].

In recent years, the scientific interest in the problems of the interaction of electromagnetic fields with matter has increased, and the particular interest is the study of the effect of high-frequency and ultrahighfrequency electromagnetic fields (HF and UHF EMF) on various environments. This interest is due to the perspective of using electromagnetic interference in scientific industries to intensify technological and physical-chemical processes and manage them by directly influencing the working environment. HF and UHF technological processes have been widely used and distributed in various fields of industry such as chemical, mechanical engineering, food industry, woodworking industry, pulp and paper industry, medicine, etc. Examples of such electric and magnetic fields applications are technologies for separating constituents of an inhomogeneous medium, as well as a variety of applications HF and UHF EMF in the technological processes of heating and heat treatment, drying, thawing, etc. [9].

Unlike the methods of influence on the continuous media, the effect of HF and UHF EMF has a number of advantages. So, firstly, electromagnetic waves extend over sufficiently large distances into the object until complete attenuation, and we can talk about various electro-hydrodynamic phenomena and control them in the depths of the dispersion medium. Secondly, under the influence of HF and UHF EMFs in the medium due to the dissipation of the electromagnetic field energy into heat, distributed heat sources arise. The value of the density of thermal sources is determined by the type (geometry) of the electromagnetic wave extending in the dispersion medium and the dielectric properties of the dispersion medium. Thus, for a given wave geometry for a given medium, with use of changed frequency HF and UHF EMF it is possible to carry out controlled processes of interaction of EMF with the medium (for example, heating to a given depth) $[10,11]$.

Smaller applications so far low-intensity fields have been found, although numerous studies in this area also make it possible to conclude that they are promising for use in various technological processes associated with the use of disperse systems.

Previous studies [12-16] have shown that as a result of the action of the ultrahigh frequencies electromagnetic field (30-300 MHz), the optical and electrical properties of the silver halides, iron and aluminum 
hydroxides sols are changed. It was found that the effectiveness of electromagnetic influence depended on the frequency, field strength, exposure time and concentration of the dispersed phase of the sol. Each disperse system is sensitive to the action of a field of strictly defined frequencies. It is possible to significantly change the stability of these disperse systems by varying the field frequency and the exposure time. All previous experiments were carried out when the field affected directly on the sol [16]. At the same time, in our studies and studies of other authors, it is asserted that electromagnetic fields primarily affect water, changing its supramolecular organization [17-19]. Therefore, it was of interest to study the processes of formation of a dispersed phase particles in a medium with a modified field structure. As an object of study, an AgI sol with a negative charge of particles was chosen. The purpose of the study is to evaluate the influence of the electromagnetic field on the kinetics of formation and stability of silver iodide sols, based on the measurement of their optical properties.

\section{Method}

The AgI sols, as a classic example of hydrophobic sols, were prepared by the reaction (1):

$$
\mathrm{AgNO}_{3}+\mathrm{KI}=\mathrm{AgI}+\mathrm{KNO}_{3}
$$

Schematically, the micelle structure of the silver iodide sol obtained with an excess of KI can be represented as follows (2):

$$
\left\{[\mathrm{AgI}]_{\mathrm{m}} \cdot \mathrm{nI} \mathrm{I}^{-} \cdot(\mathrm{n}-\mathrm{x}) \mathrm{K}^{+}\right\}^{\mathrm{x}-} \mathrm{xK}^{+} .
$$

$\mathrm{AgNO}_{3}(99 \%$ pure) and $\mathrm{KI}$ (99\% pure) were used as a reagents. To prepare the sol $5 \mathrm{~mL}$ of a $0.1 \mathrm{M} \mathrm{KI}$ solution was added to $25 \mathrm{~mL}$ of water purified by reverse osmosis. With stirring, a $0.1 \mathrm{M}$ of $\mathrm{AgNO}_{3}$ solution was gradually added in an amount necessary to produce a sol of the desired concentration. The concentration of the obtained sol was calculated with use of the reaction equation, taking into account the $100 \%$ yield of $\mathrm{AgI}$ (solubility product of $\mathrm{AgI}$ is $8.3 \times 10^{-17}$ ).

The light transmission measurements were carried out with use of a CPC-2 colorimetric spectrometer at a wavelength of $440 \mathrm{~nm}$ and a temperature of $22-24^{\circ} \mathrm{C}$. Water was used as a standard solution. The length of the cuvette was $5 \mathrm{~cm}$.

A high-frequency (HF) signal generator G3-19A, allowing to vary the frequency of the EM field in the range 30-200 MHz, was used to irradiate water. The voltage at the HF electrodes was 20-22 V. The generator power was $1 \mathrm{~W}$. Irradiation of water was carried out in a $50 \mathrm{~mL}$ capacitive cell made of glass (Fig. 1). The cell consisted of a glass cup with a volume of $50 \mathrm{~mL}$ with an internal HF Wood's alloy electrode and an external electrode made of aluminum foil closely adhering to the outer surface of the cell. HF-electrodes were connected to the HF-generator with the help of a RF connector RC-75.

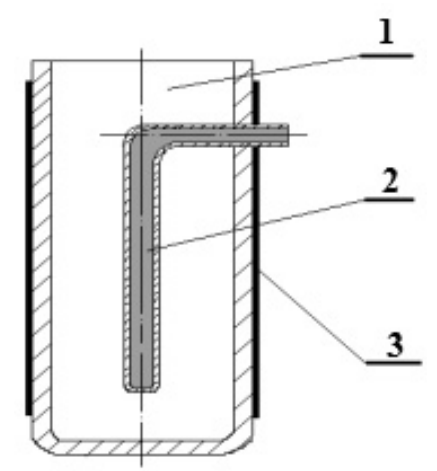

$$
1 \text { - glass cup; } 2 \text { - internal electrode; } 3 \text { - external electrode }
$$

Figure 1. HF cell structure

Water with a specific electric conductivity of $1.4 \times 10^{-4} \mathrm{~S} / \mathrm{cm}$ was used. The water was irradiated with a field of 170 and $180 \mathrm{MHz}$ for 1-3 hours. The choice of frequencies is due to the fact that it was shown earlier that the maximum change in the properties of water is observed as a result of the action of the field at a frequency of $170 \mathrm{MHz}$, and the maximum change in the properties of the sol is at $180 \mathrm{MHz}$ [5, 4]. After irradiating the water, the change in its electrical conductivity and $\mathrm{pH}$ was recorded (Table 1). In our experiments, a more noticed change in the water properties corresponded to $\mathrm{f}=180 \mathrm{MHz}$ so that the electrical conductivity changed almost 3 times, and the $\mathrm{pH}$ was changed more than one. 
Change in the electrical conductivity of water as a result of electromagnetic interference

\begin{tabular}{|l|c|c|c|}
\hline $\mathrm{f}, \mathrm{MHz}$ & 0 & 170 & 180 \\
\hline $\mathfrak{x} \cdot 10^{4}, \mathrm{~S} / \mathrm{cm}$ & $1.4 \pm 0.2$ & $3.0 \pm 0.3$ & $4.1 \pm 0.6$ \\
\hline $\mathrm{pH}$ & $6.5 \pm 0.1$ & $7.4 \pm 0.3$ & $7.6 \pm 0.2$ \\
\hline
\end{tabular}

Sols with a concentration of 0.1 and $0.2 \%$ were prepared by pouring the reagent solutions either to the non-irradiated control sample or to irradiated water ( $\mathrm{f}=170$ or $180 \mathrm{MHz}$ ). Their light transmission was measured every 20 minutes. The Table 1 data indicate that as a result of the influence of the electromagnetic field, the water properties changed, so that the properties of the sols prepared with irradiated water could also be expected to change.

\section{Results and discussion}

Silver iodide sols are formed almost immediately after mixing the reagents, as evidenced by a lower light transmission of the resulting system compared to the light transmission of water. They are metastable and over time, auto-coagulation processes occur in them, which can be noticed in a fairly rapid decrease in light transmission. With increasing sol concentration, the rate of the auto-coagulation process increases (Table 2). For further studies, 0.1 and $0.2 \%$ of AgI sol was chosen, because the auto-coagulation proceeds rapidly enough in them, which makes it possible to compare the kinetics of this process for irradiated and nonirradiated systems.

Ta b l e 2

Change in light transmission ( $T, \%)$ of AgI sols of different concentrations with time

\begin{tabular}{|c|c|c|c|c|}
\hline \multirow{2}{*}{$t$, days } & \multicolumn{4}{|c|}{$T, \%$} \\
\hline & $C=0.01 \%$ & $C=0.02 \%$ & $C=0.1 \%$ & $C=0.2 \%$ \\
\hline 0 & $97 \pm 2$ & $94 \pm 2$ & $83 \pm 2$ & $75 \pm 3$ \\
\hline 1 & $51 \pm 2$ & $50 \pm 5$ & Precipitate & Precipitate \\
\hline 2 & $38 \pm 3$ & $39 \pm 4$ & & \\
\hline 3 & $34 \pm 6$ & $32 \pm 2$ & & \\
\hline 4 & $24 \pm 2$ & $22 \pm 1$ & & \\
\hline 5 & $19 \pm 2$ & $18 \pm 2$ & & \\
\hline 6 & Precipitate & Precipitate & & \\
\hline
\end{tabular}

Studies have shown that the sols prepared in irradiated water $(170 \mathrm{MHz})$ initially have a higher light transmission: $87 \pm 1 \%(0.1 \%$ sol $)$ and $80 \pm 2 \%(0.2 \%$ sol $)$. For control samples, these values were $83 \pm 2 \%$ and $75 \pm 3 \%$, respectively (Table 2). Over time, the light transmission in all disperse systems decreased, but in the samples prepared in irradiated water it decreased to a much lesser extent. This is especially true for $0.2 \%$ sols so as at the end of the experiment, the difference in light transmission of the sol was $9 \pm 2 \%$ (Fig. 2, 3).

The values of light transmission and its time variation for $0.2 \%$ of $\mathrm{AgI}$ sols prepared in irradiated water with a field of $180 \mathrm{MHz}$ are given in Table 3. In this case, the field effect proved to be ineffective. Thus, the AgI sols prepared in irradiated water with a field of $170 \mathrm{MHz}$ were more susceptible to field action than those prepared on water irradiated at a $180 \mathrm{MHz}$ field. Thus, it can be affirmed that the influence of an electromagnetic field on water dispersions is selective. The determining parameter is a frequency of an applied field.

T a b l e 3

Change in time of light transmission of $0.2 \%$ AgI sols prepared in irradiated water with a field of $180 \mathrm{MHz}$

\begin{tabular}{|c|c|c|}
\hline $\mathrm{t}, \mathrm{min}$ & $\begin{array}{c}\mathrm{T}, \% \\
\text { control sample }\end{array}$ & $\begin{array}{c}\mathrm{T}, \% \\
\text { AgI sol in irradiated water }\end{array}$ \\
\hline 0 & 58 & 59 \\
\hline 30 & 46 & 47 \\
\hline 60 & 39 & 41 \\
\hline 90 & 34 & 35 \\
\hline 120 & 27 & 28 \\
\hline
\end{tabular}




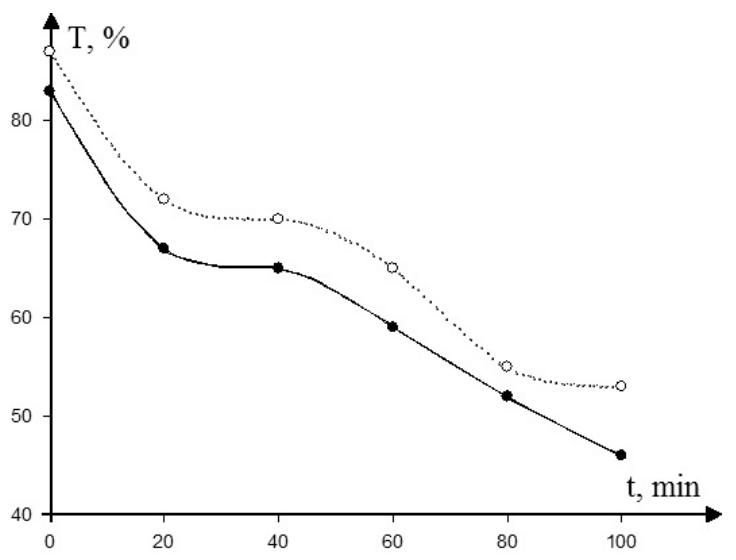

$\mathrm{AgI}$ sol in irradiated water $(\mathrm{C}=0.1 \%)$

$f=170 \mathrm{MHz}, \mathrm{t}_{\text {irr }}=1 \mathrm{~h}, \lambda=440 \mathrm{~nm}, \mathrm{C}=0.1 \%$

Figure 2. Change in time of light transmission of AgI sols prepared in irradiated and non-irradiated water

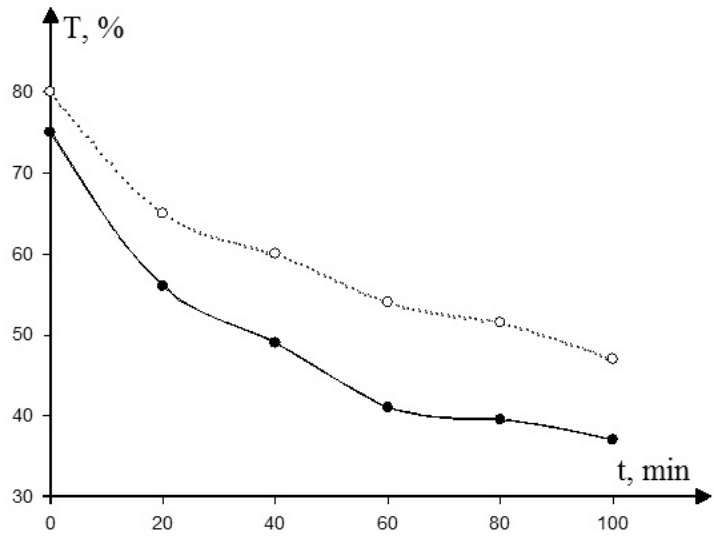

- control sample a... AgI sol in irradiated water $(\mathrm{C}=0.2 \%)$

$f=170 \mathrm{MHz}, t_{\text {irr }}=1 \mathrm{~h}, \lambda=440 \mathrm{~nm}, C=0.2 \%$

Figure 3. Change in time of light transmission of AgI sols prepared in irradiated and non-irradiated water

The dependence of the effectiveness of the electromagnetic effect on its duration was studied. The increase in time of irradiation of water, which was then used to prepare the sols, increased their stability to 3 hours (Fig. 4, 5).

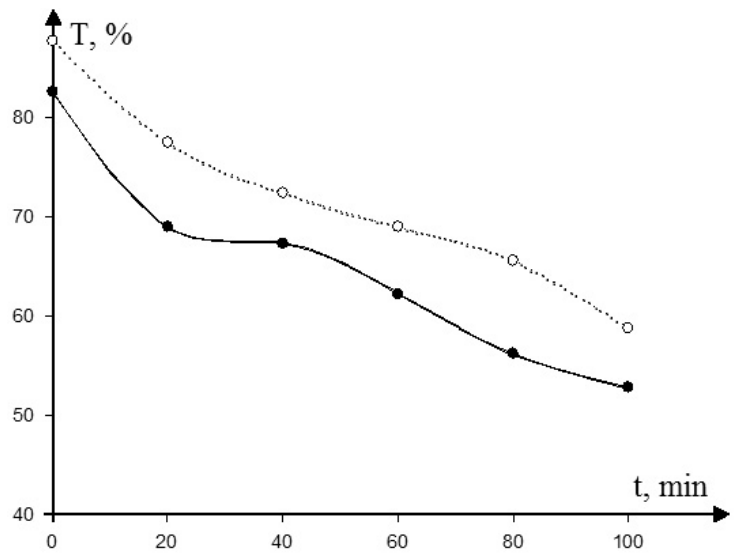

control sample

$\mathrm{AgI}$ sol in irradiated water $(\mathrm{t}=2 \mathrm{~h})$

$$
\mathrm{f}=170 \mathrm{MHz}, \mathrm{t}_{\text {irr }}=2 \mathrm{~h}, \lambda=440 \mathrm{~nm}
$$

Figure 4. Change in time of light transmission of $0.1 \%$ AgI sols prepared in irradiated and non-irradiated water

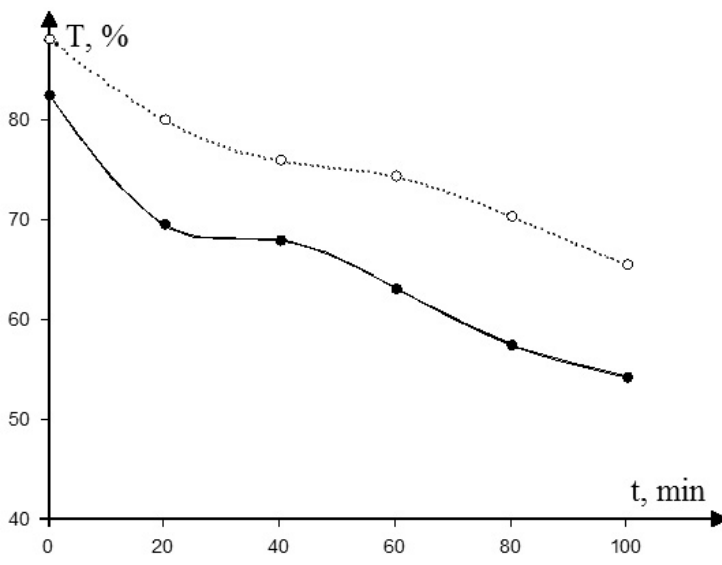

$$
\text { AgI sol in irradiated water }(\mathrm{t}=3 \mathrm{~h})
$$

$$
\mathrm{f}=170 \mathrm{MHz}, \mathrm{t}_{\text {irr }}=3 \mathrm{~h}, \lambda=440 \mathrm{~nm}
$$

Figure 5. Change in time of light transmission of $0.1 \%$ AgI sols prepared in irradiated and non-irradiated water

Table 4 shows the initial light transmission values of $0.1 \%$ of AgI sols prepared in non-irradiated and irradiated ( $\mathrm{f}=170 \mathrm{MHz})$ for $1-3$ hours with water. The initial value of light transmittance $\left(\mathrm{T}_{\mathrm{in}}, \%\right)$ increased with increasing time of electromagnetic influence on water. Table 4 also gives the final light transmission values $\left(\mathrm{T}_{\mathrm{f}}, \%\right)$ after the end of the experiment $(100 \mathrm{~min})$. The transmission of light by irradiated systems during this time was reduced, as well as by non-irradiated systems, but had higher values. At the end of the experiment, it was higher by 3,7 and $14 \%$, depending on the time of field influence. 
The initial and final (after 100 min) light transmission values of $0.1 \%$ of AgI sols prepared in non-irradiated and irradiated $(f=170 \mathrm{MHz})$ water title

\begin{tabular}{|c|c|c|c|c|}
\hline \multirow{2}{*}{} & \multirow{2}{*}{ Control sample } & \multicolumn{3}{|c|}{ Irradiation time } \\
\cline { 3 - 5 } & & $1 \mathrm{~h}$ & $2 \mathrm{~h}$ & $3 \mathrm{~h}$ \\
\hline $\mathrm{T}_{\mathrm{in}}, \%$ & $83 \pm 2$ & $87 \pm 2$ & $89 \pm 1$ & $91 \pm 2$ \\
\hline $\mathrm{T}_{\mathrm{f}}, \%$ & $48 \pm 1$ & $51 \pm 2$ & $55 \pm 2$ & $62 \pm 1$ \\
\hline$\Delta \mathrm{T}, \%$ & - & 3 & 7 & 14 \\
\hline
\end{tabular}

If a solution of $\mathrm{AgNO}_{3}$ is added to the $\mathrm{KI}$ solution in small portions, then, when the AgI solubility product is reached, the crystals of the new phase begin to form. Since KI is taken in excess, the particles are charged negatively due to the selective adsorption of iodide ions. However, as $\mathrm{AgNO}_{3}$ is added, the negative charge of the particles will decrease down to zero (the neutralizating mechanism of coagulation). With further addition of the electrolyte, the surface is recharged so as the particles acquire a positive charge due to adsorption of potential-determining ions of silver. Thus, the light transmission curve of a given system as a function of the $\mathrm{AgNO}_{3}$ concentration should be characterized by a sufficiently deep minimum, which was confirmed in practice (Fig. 6).

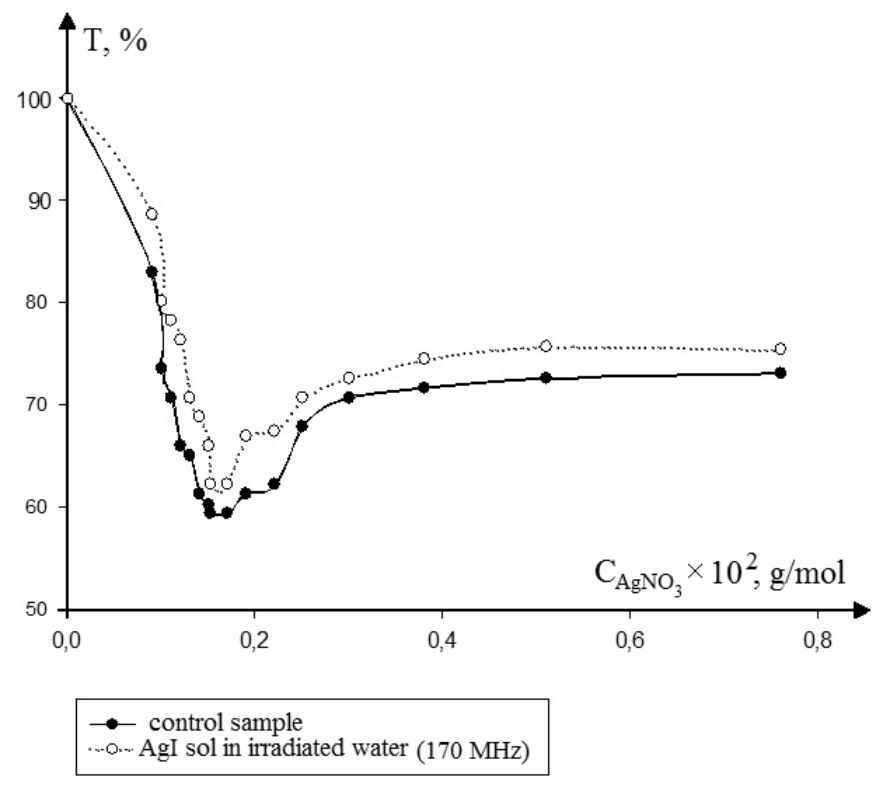

Figure 6. Change in the light transmission of $0.01 \mathrm{M} \mathrm{KI}$ solution with the addition of a $0.01 \mathrm{M} \mathrm{AgNO}_{3}$ solution

A similar experiment was carried out with a KI solution prepared in irradiated water: $0.01 \mathrm{M} \mathrm{AgNO}_{3}$ solution was added to $0.1 \mathrm{M} \mathrm{KI}$ solution in $0.1 \mathrm{~mL}$ of each one and the light transmission was recorded. The shape of the obtained curves is the same, but all points of the curve for the irradiated system are located higher. Moreover, on the descending part of the curve (negatively charged particles), the $\Delta \mathrm{T}$ value is $6-8 \%$, and on the ascending one (positively charged particles) is $2-3 \%$, which indicates that the field effect has a greater effect on sols with a negative particle charge. Because the minimum of the light transmittance curves (Figure 6) corresponds to the same $\mathrm{AgNO}_{3}$ concentration, it can be assumed that the charges of colloidal particles in irradiated and non-irradiated water coincide, and the higher light transmission of the sols in irradiated water is due to the smaller particle size of their particles.

About an increase in the stability of $0.1 \% \mathrm{AgI}$ sols prepared in water irradiated with an electromagnetic field of $170 \mathrm{MHz}$ for 3 hours we can know by the fact that the destruction of the sol and the formation of the precipitate occurred on the 4th day, while in the control sample the precipitate formed after a day. With a shorter exposure time, the precipitates in the irradiated systems formed on the third day.

The observed phenomena may be caused by the formation of smaller colloid particles in sols prepared in irradiated water. The size of the formed crystals of the dispersed phase is determined by the ratio between 
the rate of nucleation of the solid phase and the rate of their growth. The condition for the formation of nuclei of the solid phase is expressed by the equation (3) [20]:

$$
r=\frac{2 \sigma V_{M}}{R T \ln \left(C_{1} / C_{2}\right)}
$$

where $r-$ is the radius of the particles; $\sigma$ - is the surface tension at the solid-liquid interface; $V_{M}-$ is the molar volume of the dispersed phase; $R$ - is the gas constant; $T$ - is the temperature; $C_{1}$ - is the concentration of supersaturated solution; $C_{2}$ - is the concentration of saturated solution.

Analysis of this equation allows us to state that the reduction of surface tension at the solid-solution interface and the increase in the degree of supersaturation $\gamma=C_{1} / C_{2}$ facilitates the production of smaller crystals. It can be assumed that the electromagnetic action causes a decrease in the surface tension due to a change in the energy of interaction between solvent and solid phase as a result of reorganization of the supramolecular structure of water. In addition, an increase in the degree of supersaturation of the solution can be observed due to a decrease in the solubility of $\mathrm{AgI}$ in the reorganized solvent as a result of a decrease in the energy and degree of hydration of the silver ions and iodine ions.

The rate of precipitation of the dispersed phase particles in the gravitational field is proportional to the square of their radius, therefore, even a small change in particle size leads to a significant slowing of sedimentation and to an increase in the stability of the disperse system. In irradiated sols, the increase in light scattering (decrease in light transmission) with time is slower than in non-irradiated ones, which indicates a slowing of the rate of crystalline solid-phase nuclei growth.

\section{Conclusions}

The research has shown that during the exchange reactions accompanied by the formation of a slightly soluble compound (AgI) in an aqueous medium at an electromagnetic field, a slowdown in the growth of crystalline nucleus is observed. This leads to an increase in the stability of the silver iodide sols, as evidenced by higher light transmission values compared to the light transmission values of the control samples. Sedimentation occurred on the 4th day, while in the control samples it happened after a day. The influence of the electromagnetic field is selective and the effect is noticed only as a result of the action of a field of a certain frequency on the water. With increasing irradiation time, the efficiency of electromagnetic influence increases.

\section{References}

1 Щукин Е.Д. Коллоидная химия: учеб. пособие / Е.Д. Щукин. — М.: Высш. шк., 2004. — 234 с.

2 Trau M. Formation of various structures in colloidal dispersions upon application of a constant electric field / M. Trau. London: Nature, 1995. - $549 \mathrm{p}$.

3 Морозов К.И. Анизотропная диффузия коллоидных феррочастиц в магнитном поле / К.И. Морозов // Коллоидный журнал. - 1998. - Т. 60, № 2. - С. 222-226.

4 Русакова Н.Н. Влияние магнитного поля на реологические свойства магнитных коллоидов на основе магнетита, синтезированного из водно-органических сред / Н.Н. Русакова // Изв. вузов. Химия и хим. технол. — 1997. — Т. 40, № 6. C. 71-76.

5 Комаров В.С. Усиление коалесценции капель жидкости под действием электрического поля / В.С. Комаров // Весці АН Беларусі. Сер. хім. наук. - 1995. - № 3. - С. 18-22.

6 Щенкин А.К. Аналитическое и численное исследование характеристик капли с заряженным ядром конденсации во внешнем электрическом поле / А.К. Щенкин // Коллоидный журн. - 2002. — Т. 64, № 4. - С. 541-551.

7 Zhang X. Coalescence of liquid droplets under the action of an electric field / X. Zhang // Separ. Sci. and Technol. -1995. — T. 30, No. 7. - P. 7-9.

8 Miura N. Microwave dielectric study of water structure in the hydration process of cement paste / N. Miura, N. Shinyashiki, S. Yagihara, M. Shiotsubo // J. Am. Ceram. Soc. — 1998. — Vol. 81. — P. 213-216.

9 Галимбеков А.Д. Некоторые аспекты взаимодействия электромагнитных полей с поляризующими средами: автореф. дис. ... д-ра физ.-мат. наук: 01.04.13 - «Электрофизика. Электрофизические установки» / А.Д. Галимбеков. - Уфа, 2007. $-54 \mathrm{c}$.

10 Гапочка Л.Д. Воздействие электромагнитного излучения КВЧ- и СВЧ-диапазонов на жидкую воду / Л.Д. Гапочка, М.Д. Гапочка, А.Ф. Королев // Вестн. МГУ. Сер. Физ. астрон. — 1994. — Т. 35, № 4. — С. 71-76.

11 Суфьянов Р.Р. Исследование воздействия высокочастотного электромагнитного поля на нефтяные шламы: автореф. дис. ... канд. техн. наук: 05.09.10 - «Электротехнология» / Р.Р. Суфьянов. — Уфа, 2005. — $131 \mathrm{c.}$

12 Стась И.Е. Влияние высокочастотного электромагнитного поля на критическую концентрацию мицеллообразования в водных растворах додецилсульфата натрия / И.Е. Стась, О.А. Михайлова // Журн. физ. хим. — 2009. — Т. 83, № 2. C. 324,325 . 
13 Стась И.Е. Исследование влияния электромагнитного поля на оптические свойства и устойчивость золя гидроксида алюминия / И.Е. Стась, Л.Ю. Репейкова // Известия АлтГУ. — 2011. — Т. 3, № 1. — С. 137-141.

14 Репейкова Л.Ю. Кинетика коагуляции золя гидроксида железа под воздействием электромагнитного поля / Л.Ю. Репейкова, И.Е. Стась // Ползуновский вестн. — 2010. — № 3. - С. 55-58.

15 Репейкова Л.Ю. Исследование влияния электромагнитного поля на оптические свойства и устойчивость золей гидроксида алюминия / Л.Ю. Репейкова, И.Е. Стась // Известия АлтГУ. — 2011. - Т. 1, № 3. — С. 194, 195.

16 Стась И.Е. Физико-химические закономерности эволюции коллоидных наносистем в жидкой дисперсионной среде под влиянием электромагнитных полей: учеб. пособие / И.Е. Стась, Л.Ю. Репейкова. - Барнаул: Изд-во Алтайского ун-та, 2013. - $100 \mathrm{c}$.

17 Стехин А.А. Структурированная вода: нелинейные эффекты: учеб. пособие / А.А. Стехин, Г.А. Яковлева. - М.: Издво ЛКИ, 2008. - $320 \mathrm{c.}$

18 Стась И.Е. Влияние высокочастотного электромагнитного поля на физико-химические свойства воды и ее спектральные характеристики / И.Е. Стась, А.П. Бессонова // Ползуновский вестн. — 2008. — № 3. — С. 305-309.

19 Саркисов Г.Н. Структурные модели воды / Г.Н. Саркисов // Успехи физических наук. - 2006. — Т. 176, № 8. C. $833-845$.

20 Берестенева 3.Я. О механизме образования коллоидных частиц: учеб. пособие / 3.Я. Берестенева. - М.: Успехи химии, 1955. - 249 с.

\title{
И.Е. Стась
}

\section{Электрмагниттік өрістің күміс йодиді золінің тұрақтылығына әсері}

\begin{abstract}
Аса жоғары жиіліктегі электрмагниттік өрістің тазартылған суға әсерінен оның электрөткізгіштігі мен pH көрсеткіші мәнінің жоғарлауы байқалған, ол молекулалық деңгейден жоғары судың өзгерісімен түсіндіріледі. Турбидиметрия әдісімен сәулеленген суда күміс иодиді мысалында кристалдық фаза түзінділерінің түзілу кинетикасы зерттелді. Сәулеленген суда AgI кристалдарының өсуі баяулайтыны байқалған. Электрмагниттік әсер ету тиімділігі сәулеленудің жиілігі мен уақытына тәуелді болады, сонда сәулелену уақыты 3 сағ, ал жиілігі 170 МГц болатын өріс әсері тиімдірек екені анықталды. Сәулелену әсеріне ұшыраған сумен дайындалған зольдің ыдырауы 4-ші күні, ал бақылау үлгілерінде 24 сағ кейін жүретіні белгілі болды. Сәулеленген суда кристалдық түзінділердің өсуі аралық кернеудің өзгеруінен және AgI тұзының ерігіштігінің азаюынан болуы мүмкін деп түсіндірілді.
\end{abstract}

Кілт сөздер: су, күміс йодиді золі, жарықөткізу, тұрақтылық, электрмагниттік өріс, жиілік, сәулелену уақыты.

\author{
И.Е. Стась
}

\section{Влияние электромагнитного поля на устойчивость золей йодида серебра}

\begin{abstract}
Показано, что воздействие электромагнитного поля ультравысоких частот на очищенную воду приводит к значительному увеличению ее электропроводности и $\mathrm{pH}$, что интерпретировано как изменение надмолекулярной организации воды. Методом турбидиметрии изучена кинетика образования зародышей кристаллической фазы в облученной воде на примере йодида серебра. Доказано, что в облученной воде замедляется рост кристаллов AgI, что проявляется в более медленном снижении светопропускания золя во времени. Эффективность электромагнитного воздействия зависит от частоты и времени облучения - максимальный эффект достигается при воздействии поля частотой 170 МГц и времени облучения, равном 3 ч. Разрушение золей, приготовленных с помощью облученной воды, происходит на 4-е сутки, в то время как в контрольных образцах — через 24 ч. Отмечено, что в облученной воде замедляется рост кристаллических зародышей вследствие изменения пограничного натяжения и снижения растворимости AgI.
\end{abstract}

Ключевые слова: вода, золь йодида серебра, светопропускание, устойчивость, электромагнитное поле, частота, время облучения.

\section{References}

1 Shchukin, E. (2004). Kolloidnaia khimiia [Colloid Chemistry]. Moscow: Vysshaia shkola [in Russian].

2 Trau, M. (1995). Formation of various structures in colloidal dispersions upon application of a constant electric field. London, Gr. Brit.: Nature. 
3 Morozov, K.I. (1998). Anizotropnaia diffuziia kolloidnykh ferrochastits v mahnitnom pole [Anisotropic diffusion of colloidal ferro-particles in a magnetic field]. Kolloidnyi zhurnal - Colloid Journal, 60, 2, 222-226 [in Russian].

4 Rusakova, N.N. (1997). Vliianie mahnitnoho polia na reolohicheskie svoistva mahnitnykh kolloidov na osnove mahnetita, sintezirovannoho iz vodno-orhanicheskikh sred [Effect of magnetic field on the rheological properties of magnetic colloids based on magnetite synthesized from water-organic media]. Izvestiia vuzov. Khimiia i khimicheskaia tekhnolohiia - News of universities. Chemistry and chemical technology, 40, 6, 71-76 [in Russian].

5 Komarov, V.S. (1995). Usileniie koalestsentsii kapel zhidkosti pod deistviem elektricheskoho polia [Enhancing the coalescence of liquid droplets under the action of an electric field]. Vestsi AN Belarusi. Ser. khim. nauk. - Bulletin of the Academy of Sciences of Belarus. Chemistry Series, 23, 3, 18-22 [in Russian].

6 Shchenkin, A.K. (2002). Analiticheskoe i chislennoe issledovanie kharakteristik kapli s zariazhennym yadrom kondensatsii vo vneshnem ehlektricheskom pole [Analytical and numerical study of the characteristics of a droplet with a charged condensation core in an external electric field]. Kolloidnyi zhurnal - Colloid Journal, 64, 4, 541-551 [in Russian].

7 Zhang, X. (1995). Coalescence of liquid droplets under the action of an electric field. Separ. Sci. and Technol., 30(7), 7-9.

8 Miura, N., Shinyashiki, N., Yagihara, S., \& Shiotsubo, M. (1998). Microwave dielectric study of water structure in the hydration process of cement paste. J. Am. Ceram. Soc., 81(3), 213-216.

9 Galimbekov, A.D. (2007). Nekotorye aspekty vzaimodeistviia elektromahnitnykh polei s poliarizuiushchimi sredami [Some aspects of interaction of electromagnetic fields with polarizing media]. Extended abstract of Doctor's thesis. Ufa [in Russian].

10 Gapochka, L.D., Gapochka, M.D., \& Korolev, A.F. (1994). Vozdeistvie elektromahnitnoho izlucheniia KVCH i SVCH diapazonov na zhidkuiu vodu [Effect of electromagnetic radiation of EHF and microwave bands on liquid water]. Vestnik Moskovskoho hosudarstvennoho universiteta. Seriia Fizika. Astronomiia - Bulletin of Moscow State University. Physics. Astronomy Series, 35, 4, 71-76 [in Russian].

11 Sufyanov, R.R. (2005). Issledovanie vozdeistviia vysokochastotnoho elektromahnitnoho polia na neftianye shlamy [Investigation of the influence of high-frequency electromagnetic field on oil sludge]. Candidate's thesis. Ufa [in Russian].

12 Stas', I.E., \& Mikhailova, O.A. (2009). Vliianie vysokochastotnoho elektromahnitnoho polia na kriticheskie kontsentratsii mitselloobrazovaniia $\mathrm{v}$ vodnykh rastvorakh dodetsilsulfata natriia [Influence of high-frequency electromagnetic field on the critical concentration of micelle formation in aqueous solutions of sodium dodecyl sulfate]. Zhurnal fizicheskoi khimii - Zhurnal of Physical Chemistry, 83, 2, 324-325 [in Russian].

13 Stas', I.E., \& Repeikova, L.Yu. (2011). Issledovanie vliianiia elektromahnitnoho polia na opticheskie svoistva i ustoichivost zolia hidroksida aliuminiia [Investigation of the influence of the electromagnetic field on the optical properties and stability of the aluminum hydroxide sol]. Izvestiia Altaiskoho hosudarstvennoho universiteta - Proceedings of Altai State University, 3, 1, 137-141 [in Russian].

14 Repeikova, L.Yu., \& Stas', I.E. (2010). Kinetika koahuliatsii zolia hidroksida zheleza pod vozdeistviem elektromahnitnoho polia [Kinetics of coagulation of iron hydroxide sol under the influence of an electromagnetic field]. Polzunovskii vestnik Polzunovsky Herald, 15, 3, 55-58 [in Russian].

15 Repeikova, L.Yu., \& Stas', I.E. (2011). Issledovanie vliianiia ehlektromahnitnoho polya na opticheskiie svoistva i ustoichivost zolei hidroksida aliuminiia [Study of the influence of the electromagnetic field on the optical properties and stability of aluminum hydroxide sols]. Izvestiia Altaiskoho hosudarstvennoho universiteta - Proceedings of Altai State University, 3, 1, 194195 [in Russian].

16 Stas', I.E., \& Repeikova, L.Yu. (2013). Fiziko-khimicheskie zakonomernosti evoliutsii kolloidnykh nanosistem $v$ zhidkoi dispersionnoi srede pod vliianiem elektromahnitnykh polei [Physicochemical regularities in the evolution of colloidal nanosystems in a liquid dispersion medium under the influence of electromagnetic fields]. Barnaul: Altai Univ. Publ. [in Russian].

17 Stekhin, A.A., \& Yakovleva, G.A. (2008). Strukturirovannaia voda: nelineinye effekty [Structured Water: Nonlinear Effects]. Moscow: LKI Publ. [in Russian].

18 Stas, I.E., \& Bessonova, A.P. (2008). Vliianie vysokochastotnoho elektromahnitnoho polia na fiziko-khimicheskiie svoistva vody i ee spektralnye kharakteristiki [Influence of a high-frequency electromagnetic field on physicochemical properties of water and its spectral characteristics]. Polzunovskii vestnik - Polzunovsky Herald, 12, 3, 305-309 [in Russian].

19 Sarkisov, G.N. (2006). Strukturnye modeli vody [Structural models of water]. Uspekhi fizicheskikh nauk - Successes of physical sciences, 176, 8, 833-845 [in Russian].

20 Beresteneva, Z.Ya. (1955). O mekhanizme obrazovaniia kolloidnykh chastits [On the mechanism of formation of colloidal particles]. Moscow: Uspekhi khimii [in Russian]. 